\title{
ANALISIS DAMPAK PERUBAHAN PERILAKU SOSIAL EKONOMI MASYARAKAT DESA MAPIN REA PASCA BENCANA GEMPA BUMI
}

\author{
Fahlia $^{1}$, Edi Irawan ${ }^{1}$, Ramadhan Tasmin ${ }^{1}$ \\ ${ }^{1}$ Program Studi Ekonomi Pembangunan, Fakultas Ekonomi dan Bisnis Universitas Teknologi Sumbawa \\ *)E-mail:fahlia@utsl.ac.id
}

\begin{abstract}
ABSTRAK
Penelitian ini bertujuan untuk mengetahui (1) perubahan perilaku sosial masyarakat Desa Mapin Rea sebelum dan sesudah gempa bumi, (2) perubahan ekonomi masyarakat Desa Mapin Rea sebelum dan sesudah pasca gempa bumi. Penelitian ini adalah Mixed Method. Pengambilan sampel menggunakan teknik Simple Random Sampling yang berjumlah 83. Pengumpulan data menggunakan kuesioner. Wawancara dan dokumentasi. Teknik analisis data yang digunakan adalah statistik Paired T-test. Hasil penelitian ini menunjukkan, (1) ada perubahan perilaku sosial masyarakat Desa mapin Rea sebelum dan sesudah gempa bumi. Hal ini ditunjukkan dengan nilai value yang kurang dari 0.05. Selain itu hasil penelitian ini juga menunjukkan (1) Perubahan ekonomi Desa Mapin Rea sebelum dan sesudah gempa bumi. Hal ini ditunjukkan oleh nilai value yang kurang dari 0.05. (2) adanya perubahan ekonomi Desa Mapin Rea sebelum dan sesudah gempa bumi. Hal ini ditunjukkan oleh nilai value yang kurang dari 0.005 .
\end{abstract}

Kata kunci: Dampak Perubahan Perilaku Sosial Ekonomi, pasca gempa bumi.

\section{PENDAHULUAN}

Kehidupan sosial ekonomi masyarakat senantiasa mengalami perubahan. Perubahan-perubahan pada kehidupan masyarakat tersebut merupakan fenomena sosial yang sangat wajar, karena setiap manusia memiliki kepentingan dan aktifitas yang berbeda-beda. Seiring dengan perkembangan zaman dinamika masyarakat terlihat bahwa perubahan sosial terjadi secara terus-menerus baik itu diwilayah daerah perkotaan maupun di daerah pedesaan.

Berdasarkan dari fenomena gejala sosial dilapangan ditemukan bahwa pola perubahan struktur sosial terjadi bukan karena faktor modernisasi saja melainkan dari faktor alam seperti bencana alam gempa bumi. Perubahan sosial sendiri bisa diartikan sebagai perubahan-perubahan pada lembaga kemasyarakatan didalam suatu masyarakat yang mempengaruhi sistem sosialnya.

Kondisi-kondisi gejala sosial yang menyebabkan terjadinya perubahan-perubahan pada aspek sosial antara lain kondisi ekonomi, teknologi dan georafis. Perubahan ini tidak hanya disebabkan faktor internal, tetapi juga disebabkan oleh faktor eksternal seperti siklus. Pergerakan bumi yang terjadi beberapa bulan terakhir menyebabkan sering terjadinya bencana alam gempa bumi. Akibat bencana alam gempa bumi yang terjadi secara langsung mau tidak mau memaksa masyarakat tentunya mengubah tatanan kehidupan sosial dilingkungannya.

Dampak gempa bumi berkekuatan 7.0 yang dimuktahirkan 6,9 Magnitude/SR pada tanggal 19 agustus 2018 yang mengguncang kabupaten Sumbawa. Sebanyak 15 kecamatan di Kabupaten Sumbawa diketahui merasakan dampak guncangan gempa bumi. Dari jumlah tersebut, tiga kecamatan yakni Kecamatan Buer, Alas dan Alas Barat mengalami dampak kerusakan terparah sebanyak 3.723 unit rumah penduduk mengalami kerusakan akibat gempa bumi. Kabupaten Sumbawa mengalami kerusakan akibat guncangan gempa bumi yang berkekuatan 7,0 SR minggu malam. Berdasarkan keputusan bupati sumbawa hasil verifikasi yang dilakukan tanggal 25 agustus 2018 sampai dengan tanggal 17 september 2018 terhadap kerusakan rumah korban bencana gempa bumi di kabupaten sumbawa tahun 2018 dapat di lihat dengan rincian Tabel 1.1 sebagai berikut:

Tabel 1. Data verifikasi kerusakan rumah korban bencana gempa bumi

\begin{tabular}{lcccc}
\hline \multirow{2}{*}{ Kecamatan } & \multicolumn{3}{c}{ Kriteria kerusakan } & \multirow{2}{*}{ Jumlah } \\
\cline { 2 - 4 } Buer & 86 & 1 & 69 & 159 \\
Alas & 66 & 161 & 599 & 826 \\
Alas Barat & 22 & 447 & 419 & 2.288 \\
Total & & & & 3.273 \\
\hline
\end{tabular}

Sumber: Keputusan Bupati data verifikasi rumah rusak No.1015 Tahun 2018.

Berdasarkan tabel diatas Kecamatan Alas Barat merupakan salah satu kecamatan yang memiliki kerusakan terparah akibat gempa bumi dengan jumlah kerusakan mencapai 2.288 unit rumah penduduk mengalami kerusakan, selain itu rusaknya berbagai bangunan milik pribadi seperti rumah maupun fasilitas umum berupa sekolah, bangunan-bangunan pemerintahan dan fasilitas lainya merupakan sebagian dari kerugian fisik yang di timbulkan oleh bencana alam gempa bumi. Hampir dari sebagian besar bangunan-bangunan yang ada di kecamatan Alas Barat tersebut mengalami kerusakan parah, salah satunya adalah di Desa Mapin Rea.

Desa Mapin Rea merupakan salah satu desa yang berada di Kecamatan Alas Barat yang terkena bencana terparah akibat gempa bumi. Dampak bencana gempa bumi terlihat pada kerusakan rumah penduduk dan kerusakan infrastruktur, maupun fasilitas umum lainya. Hal ini sungguh menjadi suatu fenomena yang memprihatinkan di tengah-tengah kehidupan masyarakat. Berdasarkan data verifikasi terhadap kerusakan rumah korban di Desa Mapin Rea pasca bencana gempa bumi. Dengan rincian rumah penduduk yang rusak dapat dilihat pada Tabel 2 sebagai berikut: 
Tabel 2. Data Verivikasi Rumah Rusak Di Desa Mapin Rea

\begin{tabular}{lc}
\hline & Data Verifikasi Rumah Rusak \\
\hline Berat & 55 \\
Sedang & 225 \\
Ringan & 213 \\
$\quad$ Total & 493
\end{tabular}

Sumber: Keputusan Bupati data verifikasi rumah rusak No.1015 Tahun 2018.

Berdasarkan tabel diatas data verifikasi rumah rusak di Desa Mapin Rea dengan jumlah kerusakan mencapai 493 unit rumah warga yang mengalami kerusakan akibat gempa bumi. Dampak gempa bumi banyak merusak rumah-rumah warga, sekolah, dan tempat ibadah. Lumpuhnya kegiatan ekonomi, terutama gagal setiap warga dalam memproduksi aktivitas perekonomian menjadi terhenti, karena banyak diantara mereka yang mengungsi selama berbulan-bulan ditenda pengungsian. Akhirnya masyarakat tidak mampu untuk melakukan aktivitas perekonomian seperti hari-hari biasa.

Dampak gempa bumi bagi kehidupan sosial mengakibatkan masyarakat Desa Mapin Rea sangat dipengaruhi dari segi sosial dan adaptasi lingkungan, perubahan prekuensi, perubahan perantara sosial, masyarakat mencoba untuk memulai hidup dari "nol" dan menyesuaikan diri dengan lingkungan sekitar, akibat kerusakan yang ditimbulkan pasca gempa bumi, terganggunya ketenangan dan pola kehidupan masyarakat Mapin Rea. Selain itu kondisi kehidupan sosial Desa Mapin Rea, yang terjadi pasca bencana gempa bumi adaptasi masyarakat semakin renggang hubungan dengan sesama anggota masyarakat. Dalam kehidupan sehari-hari masyarakat lebih bersifat individualis karna mereka lebih sibuk bekerja untuk memenuhi kebutuhan keluarga masingmasing (Okwita Afrianel, 2009).

Desa Mapin Rea menghadapi kondisi dan situasi yang sangat kompleks, baik secara sosial ataupun ekonomi. Problem yang sangat mendasar adalah persoalan ekonomi, seperti gangguan pendapatan, hari kerja yang hilang, volume produksi yang hilang, tempat tinggal. Hal ini berawal dari sanitasi dampak lingkungan yang buruk, sehingga menimbulkan ketidak nyamanan bahkan dapat menjadi sumber penyakit, kehilangan harta benda menyebabkan korban menjadi tidak berdaya, dan jatuh miskin apalagi sumber matapencaharian dan pendapatan yang tidak memungkinkan. Mengakibatkan sebahagian warga hidup dalam situasi tidak memiliki penghasilan (Rusmiati, Chatarina dan Enny Hikmawati, 2012: 98).

Melihat perubahan yang terjadi pada masyarakat Desa Mapin Rea sebelum dan sesudah pasca gempa bumi, suda menjadi gambaran umum kondisi ketidak berdayaan masyarakat Desa Mapin Rea yang sangat konpleks baik dari segi sosial maupun ekonomi, sehingga peneliti termotivasi untuk mengetahui dan mengkaji secara detail, mengeksplorasikan dan mencari tahu mengenai dampak perubahan sosial ekonomi yang terjadi di Desa Mapin Rea sebelum dan sesudah gempa bumi. Apakah terjadi perubahan signifikan dari segi sosial dan ekonomi atau tidak terjadi samasekali. Sehingga peneliti tertarik untuk melakukan penelitian yang berjudul "Analisis Dampak Perubahan Sosial Ekonomi Masyarakat Desa Mapin Rea Pasca Bencana Gempa Bumi”.

\section{Rumusan Masalah}

Berdasarkan latar belakang diatas rumusan masalah penelitian ini sebagai berikut:

1. Adakah perbedaan perilaku sosial masyarakat Desa Mapin Rea sebelum dan sesudah pasca gempa bumi?

2. Adakah perubahan ekonomi masyarakat Desa Mapin Rea sebelum dan sesudah gempa bumi?

\section{Tujuan Penelitian}

Berdasarkan rumusan masalah diatas, maka tujuan penelitian ini sebagai berikut:

1. Mengetahui perubahan sosial masyarakat Desa Mapin Rea sebelum dan sesudah pasca gempa bumi.

2. Mengetahui perubahan ekonomi masyarakat Desa Mapin Rea sebelum dan sesudah pasca gempa bumi.

3.

\section{Tinjauan pustaka}

\section{Kajian Teori}

\section{Pengertian Analisis Dampak}

Analisis dampak adalah kajian mengenai dampak besar yang membawa perubahan pada lingkungan. Analisis dampak dalam istila asing disebut dengan "environmental impact analisis", "environmental Impact Statemen", "environmental impact assessment" atau "environmental assessment and statement". Profesor Otto Soemarwoto, menggunakan istilah tersebut dengan analisis dampak yang merujuk pada perubahan lingkungan, sedangkan Profesor. St. Munadjat Danusaputro, mengistilahkanya dengan "pernyataan dampak lingkungan" sebagai terjemahan dari "environmental impact statement". Semua istilah diatas menunjukan pada pengertian dampak dan perubahan perlu dikaji (dianalisis) lebih dahulu secara seksama berdasarkan kajian ini akan dapat di identifikasi dampak-dampak yang timbul, baik yang bermanfaat maupun yang merugikan bagi kehidupan manusia. (S.H.T. Siahaan, 2004).

\section{Pengertian Perubahan Sosial}

Menurut Nur indah aryani, okta hadi nurcahyono, (2014). Perubahan merupakan proses yang terus menerus terjadi dalam setiap masyarakat. Proses perubahan itu ada yang berjalan sedemikian rupa sehingga tidak terasah oleh proses pendukungnya. Gerak perubahan yang sedemikian itu di sebut evolusi. Sosiologi mempunyai gambaran adanya perubahan evolusi masyarakat dari masyarakat sederhana kedalam masyarakat modern. Proses gerak masyarakat perubahan tersebut ada dalam satu rentang tujuan ke dalam masyarakat modern.

\section{Perubahan Perilaku}

Secara garis besar, perilaku adalah tindakan atau pola respon yang dilakukan oleh seseorang pada situasi tertentu. Perilaku seseorang menyangkut tindakan atas respon hubungan timbal balik antara individu dengan lingkungan sekitarnya yang dipengaruhi oleh adat, sikap, emosi, nilai, etika, kekuasaan, persuasi atau genetika. Perilaku sosial merupakan perilaku 
yang terjadi dalam situasi sosial melalui cara orang berfikir, merasakan dan bertindak. Perubahan adalah berubah dari satu bentuk kebentuk yang lain yang berbeda dari sebelumnya. Perubahan seyogyanya mengarah pada situasi atau kondisi yang lebih baik. namun tidak dapat dipungkiri terkadang perubahan juga mengarah pada situasi atau kondisi yang kurang baik. dengan demikian perubahan perilaku adalah perubahan tindakan, sikap atau pola respon seseorang terhadap situasi dan kondisi pada lingkungan sekitarnya. (Ramadhani dalam Ira Suprihatin 2015:4).

\section{Perubahan Struktur Ekonomi}

Perubahan struktur ekonomi, secara umum disebut transformasi struktural, dapat didefisinikan sebagai suatu rangkaian perubahan yang saling tekait satu dengan yang lainnya menurut Karl Marx mengatakan bahwa perubahan ekonomi adalah perilaku produksi dan konsumsi masyarakat yang berubah. Struktur ekonomi adalah komposisi peranan masing- masing sektor dalam perekonomian baik menurut lapangan usaha maupun pembagian sektoral ke dalam sektor primer, sekunder dan tersier.

Sesuai dengan hal di atas Karl Marx dalam juga mengemukakan struktur ekonomi adalah penggerak sistem sosial yang akan menyebabkan perubahan sosial, lingkungan ekonomi menjadi dasar segala perilaku manusia. Selanjutnya Marx menyatakan bahwa kita harus mencari penyebab perubahan di dalam cara-cara produksi masyarakat daripada ide-idenya. Marx kemudian memusatkan perhatian pada proses produksi yang dilakukan manusia. Jadi jelas bahwasannya mekanisme utama pendorong perubahan adalah persoalan pemenuhan materi masyarakat.

\section{Dampak gempa bumi terhadap kerusakan fisik}

Kerugian langsung akibat bencana menjadi fokus dari banyak upaya mitigasi dan kesiapsiagaan sebagai kunci mengurangi dampak langsung. Apabila kerugian langsung dapat diatasi maka dampak sekundernya dapat dikurangi atau dicegah ekonomi yang dari teramati adalah kerugian rusak dan kehancuran perumahan dan sektor usaha yan tidak hanya berakibat pada kerugian output yang tidak dihasilkan tetapi juga kemungkinan munculnya kemiskinan sebagai akibat dari penyesuaian kondisi struktural masyarakat yang berubah.

Menurut Tim Pusat Studi Gempa Nasional (2016: 20) Akibat yang dapat dirasakan langsung pada saat gempa bumi adalah kerusakan pada rumah-rumah, tempat ibadah, ruko, gedung, perkotaan jalan raya dan lain sebagainya. Seringkali kerusakan ini di tandai dengan timbulnya korban jiwa lukaluka akibat banyak orang-orang yang terperangkap didalamnya. Berdasarkan Peraturan Mentri Pekerjaan Umum Nomor 24/Prt/M 2008 tentang pedoman pemeliharaan dan perawatan bangunan gedung. Kriteria tingkat kerusakan bangunan terbagi menjadi tiga kategori yaitu: Rusak berat, rusak sedang, dan rusak ringan. Adapun beberapa kriteria tersebut dapat dirincikan dalam bentuk Tabel 2.3 kriteria kerusakan pada bangunan pasca gempa untuk memper jelas data adalah sebagai berikut:

1. Kerusakan Berat. Bangunan hancur, sebagian rangka atap langit-langit lepas, tembok roboh dan aliran listrik terputus.
2. Kerusakan Sedang. Bangunan masih berdiri, retak-retak jendela rusak, dinding pelasteran/penutup atap lepas instalasi rusak, jendela rusak.

3. Kerusakan Ringan, jendelah ruma rusak, dan kaca rumah rusak, tembok retak.

\section{Pendekatan dan jenis penelitian}

Pendekatan dan jenis penelitian yang di gunakan dalam penelitian ini adalah gabungan kualitatif dan kuantitatif (Mixed Method). Metode gabungan berkaitan dengan penggunaan metode lebih dari satu dalam satu kegiatan yang menggunakan kualitatif dan kuantitatif. Dalam penelitian ini kualitatif dan kuantitatif digunakan sebagai bukti empiris dalam menjawab masalah penelitian agar mendapatkan hasil temuan yang lengkap (Sarwono, 2011:12).

Pendekatan dan jenis penelitian yang di gunakan dalam penelitian ini adalah gabungan kualitatif dan kuantitatif (Mixed Method). Metode gabungan berkaitan dengan penggunaan metode lebih dari satu dalam satu kegiatan yang menggunakan kualitatif dan kuantitatif. Dalam penelitian ini kualitatif dan kuantitatif digunakan sebagai bukti empiris dalam menjawab masalah penelitian agar mendapatkan hasil temuan yang lengkap (Sarwono, 2011:12).

Mixed Method adalah penelitian yang melibatkan penggunaan dua metode, yaitu metode kuantitatif dan metode kualitatif dalam studi tunggal (satu penelitian). Penggunaan dua metode ini dipandang lebih memberikan pemahaman yang lebih lengkap tentang masalah penelitian daripada penggunaan salah satu di antaranya. Penelitian metode campuran merupakan pendekatan penelitian yang mengombinasikan atau mengasosiasikan bentuk kualitatif dan bentuk kuantitatif. Pendekatan ini melibatkan asumsi-asumsi filosofis, aplikasi pendekatan-pendekatan kualitatif dan kuantitatif, serta pencampuran (mixing) kedua pendekatan tersebut dalam satu penelitian. Pendekatan ini lebih kompleks dari sekadar mengumpulkan dan menganalisis dua jenis data; tetapi juga melibatkan fungsi dari dua pendekatan penelitian tersebut secara kolektif sehingga kekuatan penelitian ini secara keseluruhan lebih besar daripada penelitian kualitatif dan kuantitatif. Mixed methods research juga disebut sebagai sebuah metodologi yang memberikan asumsi filosofis dalam menunjukkan arah atau memberi petunjuk cara pengumpulan data menganalisis data serta perpaduan pendekatan kuantitatif dan kualitatif.

\section{Hasil penelitian}

Hipotesis merupakan dugaan sementara atas rumusan masalah. Hipotesis harus di uji kebenarannya secara empiris. Pengujian hipotesis ini menggunakan analisis statistic deskriptif dan imperensial. Inferensial yang menjelaskan karakteristik responden dengan variabel-variabel penelitian (ferdinan,2006). Untuk menganalisis data yang diperoleh dalam penelitian ini maka dilakukan Uji beda dengan metode paired sample T- tes.

Uji Paired Sample T-Test digunakan untuk mengetahui apakah terdapat perbedaan rata-rata antara dua sampel (dua kelompok) yang berpasangan atau berhubungan. Untuk mendukung hasil penelitian ini mengenai analisis dampak perubahan sosial ekononomi pasca gempa, maka untuk melihat perbedaan perubahan sosial ekononomi sebelum dan sesuda pasca gempa bumi, yang terjadi di Desa Mapin Rea 
Kecamatan Alas Barat, peneliti menggunakan uji beda. Hasil akan di tunjukan pada data dibawah ini.

Tabel 4. Rangkuman uji t-testpaired samples statistik sosial sebelum dan sosial sesudah gempa

\section{Paired Samples Statistics}

\begin{tabular}{ccccc}
\hline & & & \multicolumn{2}{c}{ Std. } \\
& Mean & N & Std. Error \\
& Deviation & Mean \\
\hline Sebelum & 38.60 & 83 & 2.815 & .309 \\
Sesudah & 40.24 & 83 & 3.137 & .344 \\
\hline
\end{tabular}

\begin{tabular}{|c|c|c|c|c|c|c|}
\hline \multicolumn{7}{|c|}{ Paired Samples Test } \\
\hline & \multicolumn{3}{|c|}{ Paired Differences } & $\underline{T}$ & $\underline{\mathrm{Df}}$ & $\begin{array}{l}\text { Sig. (2- } \\
\text { tailed) }\end{array}$ \\
\hline & \multicolumn{3}{|c|}{$\begin{array}{l}95 \% \text { Confidence } \\
\text { Interval of the } \\
\text { Difference }\end{array}$} & & & \\
\hline & Mean & Lower & Upper & & & \\
\hline $\begin{array}{l}\text { Sblm } \\
\text { Sesdh }\end{array}$ & $1 . \overline{639}$ & -2.338 & -.939 & $\begin{array}{c}- \\
4.6 \\
61\end{array}$ & 82 & .000 \\
\hline
\end{tabular}

Pada output ini diperlihatkan hasil ringkasan statistik deskriptif dari kedua sampel atau data sosial sebelum gempa dan sosial sesudah gempa. Mean adalah nilai rata-rata dari kondisi sosial sebelum gempa (38.60), dan kondisi sosisal sesuda gempa (40.24) $\mathrm{N}$, adalah jumlah sampel yang digunakan.

Bagian kedua output ini adalah hasil korelasi atau hubungan antara kedua data atau variabel, output kedua ini menjelaskan apakah terdapat hubungan yang kuat yakni antara variabel sosial sebelum gempa dan variabel sosisal sesudah gempa, melalui uji korelasi dengan signifikasi .000, sebagaimana dasar pengambilan keputusan, karena signifikasi $0,000<0,05$, maka, secara signifikan terdapat hubungan korelasi antara variabel Perubahan sosial sebelum gempa dan sesudah gempa.

Diketahui bahwa nilai t-hitung untuk sosial sebelum gempa dan sesudah gempa adalah -4.661 dengan probabilitas (sig2tailed) sebesar $0,00<0,05$, maka $\mathrm{H} 0$ di tolak dan $\mathrm{H} 1$ di terima. Artinya terdapat pengaruh perbedaan rata-rata yang signifikan antara sosial sebelum dan sesudah gempa, sehingga dapat disimpulkan bahwa, terdapat perubahan perilaku yang nyata dari segi sosial setelah gempa bumi di Desa Mapin Rea.

Tabel 4. 1 Ringkasan hasil analisis t-test (paired samples statistik) sosial sebelum dan sesudah gempa bumi.

\begin{tabular}{|c|c|c|c|c|}
\hline Kelompok & Correlation & Sig. & Mean & $\mathrm{T}$ \\
\hline $\begin{array}{l}\text { sebelum } \\
\text { sesudah }\end{array}$ & .425 & 0,000 & -1.639 & -4.661 \\
\hline
\end{tabular}

Berdasarkan nilai probabilitas Uji t-test Paired Samples Statistik Perubahan Sosial sebelum dan sesudah gempa bumi uji beda mencapai (0.000), karena probabilitas (sig 2. tailed) < 0.05 maka H1 di terima dan H0 ditolak. Sehingga dapat disimpulkan bahwa signifikan, telah terjadi perubahan perilaku di Desa Mapin Rea pasca gempa bumi.
Berikut adalah deskripsi hasil wawancara responden dari tanggal 27 Mei- 5 Juni 2019 adalah sebagai berikut:

\begin{tabular}{cccc}
\hline \multicolumn{4}{c}{ Paired Samples Correlations } \\
\hline & N & Correlation & Sig. \\
\hline $\begin{array}{l}\text { Sebelum } \\
\text { Sesudah }\end{array}$ & 83 & .425 & .000 \\
\hline
\end{tabular}

Berdasarkan hasil wawancara dari 83 responden. 29 rumah rusak berat, 29 rumah rusak sedang, dan 25 rumah rusak ringan. Menyatakan bahwa pasca gempa bumi masyarakat mulai ber adaptasi dengan lingkungan berusaha menerima keadaan tersebut karena itu tentunya sudah menjadi kehendak dari sang pencipta. Mau tidak mau masyarakat harus menerima keadaan tersebut.

Selain itu masyarakat juga mengalami perubahan frekuensi yaitu masyarakat disibukkan dengan banyaknya pekerjaan, banyak diantara mereka yang sibuk mengerjakan pekerjaan rumah masing-masing. Akibat dampak dari gempa bumi Sehingga masyakat sulit untuk berkumpul dengan tetangga maupun sanak keluarga lainnya seperti kondisi hari-hari biasa.

Selain itu mereka juga mengalami ketidak adanya hubungan perantara diantara mereka karena kesibukan masing-masing, sehingga mereka tidak sempat untuk menjalin hubungan silaturahim dengan tetangga untuk bertemu dan berkumpul saja hanya pada saat tertentu saja. Kondisi sosial di Desa Mapin Rea sangat terasa perbedaanya ketika terjadi gempa bumi. Perubahan perilaku masyarakat terlihat berubah merupakan kondisi situasi yang tidak diinginkan tetapi karena kondisi yang lingkungan itu sendiri yang memaksa untuk berubah, sehinggah membuat masyarakat berubah. Dari hasil wawancara tersebut di Desa Mapin Rea. Dalam hal ini benar benar mengalami perubahan perilaku sosial pasca gempa bumi.

Tabel 4 Rangkuman uji t-testpaired samples statistik rata-rata ekonomi sebelum dan sesudah gempa

\begin{tabular}{|c|c|c|c|c|}
\hline \multicolumn{5}{|c|}{ Paired Samples Statistics } \\
\hline & Mean & $\mathrm{N}$ & $\begin{array}{c}\text { Std. } \\
\text { Deviatio } \\
\underline{\mathrm{n}}\end{array}$ & $\begin{array}{c}\text { Std. } \\
\text { Error } \\
\text { Mean }\end{array}$ \\
\hline Sebelum & 34.7711 & 83 & 2.777 & .30488 \\
\hline Sesudah & $\underline{35.3855}$ & $\underline{83}$ & $\underline{2.797}$ & .30705 \\
\hline
\end{tabular}

Pada data output ini diperlihatkan hasil ringkasan statistik deskriptif dari kedua sampel atau data ekonomi sebelum gempa dan ekonomi sesudah gempa. Mean adalah nilai ratarata dari kondisi ekonomi sebelum gempa (34.771), dan kondisi ekonomi sesudah gempa (35.3855), N, adalah jumlah sampel yang digunakan.

Bagian kedua output ini adalah hasil korelasi atau hubungan antara kedua data atau variabel, output kedua ini menjelaskan apakah terdapat hubungan yang kuat yakni antara variabel ekonomi sebelum gempa dan variabel ekonomi sesudah gempa, melalui uji korelasi dengan signifikasi .000, sebagaimana dasar pengambilan keputusan, karena signifikasi $0,000<0,05$, maka secara signifikan terdapat hubungan 
korelasi antara kedua variabel ekonomi sebelum gempa dan sesudah gempa. sehingga dapat diambil keputusan bahwa trdapat hubungan korelasi antara kedua variabel ekonomi sebelum dan sesudah gempa bumi.

Diketahui bahwa nilai t-hitung untuk variabel ekonomi sebelum gempa dan sesudah gempa adalah -3.390 dengan probabilitas signifikan sebesar $0,01<0,05$, maka H0 ditolak dan $\mathrm{H} 1$ diterima Artinya terdapat pengaruh perbedaan rata-rata yang signifikan antara ekonomi sebelum dan sesudah gempa dapat disimpulkan bahwa, terdapat perubahan yang nyata dari segi ekonomi setelah gempa bumi di Desa Mapin Rea.

Tabel 4. 2 Ringkasan hasil analisis t-test (paired samples statistik) sosial sebelum dan sesudah gempa bumi

\begin{tabular}{lcccc}
\hline Kelompok & $\begin{array}{c}\text { Correl } \\
\text { ation }\end{array}$ & Sig. & Mean & T \\
\cline { 2 - 3 } $\begin{array}{l}\text { sebelum } \\
\text { sesudah }\end{array}$ & .425 & 0,001 & -1.61446 & -3.390 \\
\hline
\end{tabular}

Berdasarkan nilai probabilitas Uji t-test Paired Samples Statistik Perubahan ekonomi sebelum dan sesudah gempa bumi uji beda mencapai (0.001), karena probabilitas (sig 2 . tailed) $<0.05$ maka H1 di terima dan H0 ditolak. Sehingga dapat disimpulkan bahwa signifikan, terjadi perubahan ekonomi di Desa Mapin Rea pasca gempa bumi.

Berdasarkan hasil wawancara klasifikasi pendapatan rata-rata yang diterima berdasarkan jenis pekerjaan, kriteria kerusakan rumah pada responden. dijelaskan bahwa, pada awal gempa bumi semua responden mengalami gangguan pendapatan yang cukup besar, bahkan responden yang bekerja sebagai petani sebanyak $74 \%$ mengalami gangguan pendapatan. Dengan ratarata perbandingan pendapatan sebelum dan sesudah gempa bumi. Pendapatan petani sebelum gempa berjumlah $\mathrm{Rp}$ $2.500 .000,2.000 .000,15.00 .000,1.000 .000$ sampai dengan 800.000. sedangkan jumlah pendapatan sesudah gempa berjumlah senilai Rp. 1.000.000, 800.000, 500.000, 600.000 sampai dengan 400.000 .

Responden yang bekerja sebagai pedagang sebanyak $6 \%$ mengalami gangguan pendapatan, dengan rata-rata perbandingan pendapatan sebelum dan sesudah gempa bumi. Pendapatan pedagang sebelum gempa berjumlah senilai Rp.5.000.000, 3.000.000, dan 2.000.000. sedangkan pendapatan pedagang setelah gempa, mengalami gangguan dan penurunan secara drastis berjumlah Rp. 500.000. karena kebanyakan pedagang mengalami kerusakan rumah dengan kriteria rumah rusak berat. Sehingga seluruh bangunan kios dan toko hancur dan roboh.
Sedangkan responden yang bekerja sebagai wiraswasta sebanyak 14\% mengalami gangguan pendapatan. Dengan ratarata perbandingan pendapatan sebelum dan sesudah gempa bumi, pendapatan wiraswasta sebelum gempa berjumlah Rp. 3.000.000, 2.500.000, 2.000.000, sampai dengan 1.500.000. sedangkan pendapatan sesudah gempa berjumlah Rp. 1.500 .000 , $1.000 .000,800.00,700.000$, sampai dengan 500.000 .

Responden yang bekerja sebagai PNS (Pegawai Negeri Sipil) sebanyak $7 \%$ mengalami gangguan pendapatan. Dengan ratarata perbandingan pendapatan sebelum dan sesudah gempa bumi, pendapatan PNS sebelum gempa, gaji pokok ditamba dengan pendapatan tambahan diluar berjumlah senilai Rp. 3.500.000, 3.000.000. sedangkan pendapatan sesudah gempa berjumlah Rp. 2.560.600 dan 2.476.700. Hal ini menunjukan bahwa masyarakat Desa Mapin Rea benar-benar mengalami gangguan dari segi pendapatan pasca gempa bumi.

\section{Daftar Pustaka}

Afrianel okwita. "Perubahan kehidupan sosial ekonomi masyarakat pasca bencanaN gempa 30 september 2009 nagari gunung padang alai kecamatan $V$ kota timur kabupaten padang pariama" Jurnal Dimensi Vol.1. Koto Timur Kabupaten Padang Pariaman.

Nur Indah Aryani, \& Okta Handi Nurcahyano. 2014. "Digitalisasi Pasar Taradisional: Prespekti Teori Pearubahan Sosial. dalam jurnal analisa sosiologi.

Pusat Studi Gmpa Nasional (PuSGeN) (2016). "Pusat Litbang Perumahan dan Pemungkiman Balitbang PUPR, Badap Penelitian dan Pengembangan Kementrian Pekerja Umum dan Perumahan Rakyat" Jurnal: Penilaian kerusakan pada gedung. Vol.3, No. 1.

Rusmiati, Chatarina dan Enny Hikmawati. 2012. "Penanganan Dampak Sosial Psikologis Korban Bencana Gunungh Merapi”. Dalam Jurnal Psikologis Korban Bencana, Vol. 17. NO.2, hlm. 98. (2012).

Suprihatin Ira. 2014. "Perubahan Perilaku Bergotong Royong Masyarakat Sekitar Perusahaan Tambang Batu Bara di Desa Mula Warman Kecamatan Tanggerong seberang”. Dalam Jurnal sosiatri 2014 (3): 63-77. ISSN.

Saihaan S.H.T, 2004. Hukum Pembangunan dan Ekologi Pembangunan. Ed. 2 - Jakarta: Erlangga.

Sarwono, jonathan. 2011. Metode Penelitian Kuantitatif dan Kualitatif. Yogyakarta: Graha Ilmu. 